Volume 11 Number 1, January-March 2017: pp. 39-64. Copyright (c) 2017 FIAT JUSTISIA. Faculty of Law, Lampung University, Bandarlampung, Lampung, Indonesia.

ISSN: 1978-5186 | e-ISSN: 2477-6238.

Open Access: http://jurnal.fh.unila.ac.id/index.php/fiat

Fiat Justisia is licensed under a Creative Commons Attribution 4.0 International License, which permits unrestricted use, distribution, and reproduction in any medium, provided the

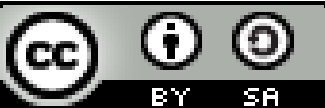
original work is properly cited.

\title{
Identification and Law Review of Closed Agreements in Indonesia: Analysis of Case Closed Agreements PT. Pelindo II Persero in Teluk Bayur Port, Padang, West Sumatra Province
}

\author{
Dani Amran Hakim \\ Association of Legal Aid and Human Rights Indonesia, Lampung \\ daniamranhakim@yahoo.com
}

\begin{abstract}
This paper aims to identify and analyze on a law review of closed agreements by the Law Number 5 of 1999 on Prohibition of Monopolistic Practices and Unfair Competition as well as how the legal analysis of the alleged cases of agreements covered by PT Pelindo II (Persero) which occurred in Teluk Bayur in Padang, West Sumatra. In a legal review of the closed agreement as mentioned in Article 15 and 19 of Law Unfair Competition, it can be concluded that the closed agreements carried out in a business relationship tend to be favorable to the parties entered into a secretive and harmful for others who are not inside the circle of the agreement. Case Lease Agreement of Land between PT Pelindo II (Persero) with a third party is tying product whereas clauses designation stevedoring companies owned by PT Pelindo II (Persero) for the tenants are tied product, and the agreement is contrary to the principle of fair business competition especially Article 15 paragraph (2) of Law Number 5 of 1999 on the Prohibition of Monopolistic Practices and Unfair Business Competition.
\end{abstract}

Keyword: Identification, Closed Agreements, PT Pelindo II

\section{A. Introduction}

Based on, Article 33 of the Constitution of the Indonesian Republic Year 1945 declares that the economic system adopted by the state is the democratic economy which aims to create prosperity and social justice as the purpose of the economic development. Based on that, in formulating economic policies the state should always try to eliminate the negative traits embodied in the liberal and socialist economic systems, namely free fight 
liberalism that justifies the exploitation of people, etatism where the state and its apparatus minimize the potential and the creativity of economic units outside the state sector, and economic centralization on one monopolistic groups which is detrimental to society. ${ }^{1}$ The principle of Article 33 of the Constitution of 1945 which should also be included in business activities to minimize the emerge of agreements and business activities containing any element of unfairness to the weaker economic or social agents with excuses of maintaining fair competition.

It is certain that in various business activities there is competition among businesses. People in business will seek to create, pack, and market their products either goods/services as good as possible to attract the consumer Competition in business could have positive implications, on the contrary, it can be negative if it is executed with negative behavior and lead to uncompetitive economic activity. ${ }^{2}$

Each business agent will be forced to make every effort to improve their service and managerial competence, also to perform innovation to improve the qualities of their products and services to outperform their competitors. This is certainly a positive impact on consumers because it means the best products may be available at a minimum price. But in fact, many business agents are trying to deprive any competition with the aim to take advantage as high as possible. Together, these business agents create favorable agreements among themselves.

Essentially, an agreement is a fundamental interest in the business as the basis of most commercial transactions, such as buying and selling goods, land, credit, insurance, transportation of goods, the establishment of business organizations and also labors. Under the Code Civil (Civil Code), the arrangement of legal agreement can be found in most of Book III of the Civil Code, which is specifically regulated in Article 1313-1351 of the Civil Code. ${ }^{3}$ An agreement is a legal nexus between two people or two parties, and the other party is obliged to meet a certain demand. Moreover, it is a legal event where a person gives his/her assurance to another person or where the two people agree to do something for each other. ${ }^{4}$

\footnotetext{
${ }^{1}$ Yani, Ahmad and Widjaja, Gunawan. Seri Hukum Bisnis Anti Monopoli. Jakarta: Rajawali Pers, (1999), p. 4.

${ }^{2}$ Strictly speaking economic activities are the run the company, namely an activity that wisdom and insight that its meant to do with some ways: a) in continuous and uninterrupted or an activity continuing; b) openly unauthorized (not illegal) in accordance with the provisions applicable regulations; c) these activities are done in order to gain advantage to themselves and other people. See Hartono, Sri Redjeki, Hukum Ekonomi Indonesia. Malang: Bayumedia, (2007), p. 40.

${ }^{3}$ Widjaja, Gunawan, Memahami Prinsip Keterbukaan (Aanvullend Recht) Dalam Hukum Perdata. Jakarta: Grafindo Persada, (2007), p. 247.

${ }^{4}$ Subekti, Hukum Perjanjian, Jakarta: Intermasa, (1996), p. 29.
} 
Various literatures also mention that if an agreement has fulfilled all the terms and conditions in accordance with the law of treaties, that agreement is binding and enforceable and valid as the law creates legal effect and shall be met by the parties concerned, as has been set out in Article 1338 Paragraph (1) of the Civil Code.

Later, the Law No. 5 on 1999 of Prohibition of Monopolistic Practices and Unfair Competition emerges as an instrument that encourages economic efficiency and fairness climate for businesses. This law is also arranged to avoid unhealthy and unnatural economic practices. The Law No. 5 Yo 1999 also regulates prohibited agreements which are divided into 13 (thirteen) types, one of which will be parsed, examined and analyzed case by case in this paper that covers the agreements.

Alleged cases of covered agreement that will be analyzed in this paper is a case involving PT Pelabuhan Indonesia II (Persero) which is the issue of lease agreement for land between PT Pelabuhan Indonesia II (Persero) with third parties in Teluk Bayur containing provisions that PT Pelabuhan Indonesia II (Persero) requires the Third Party to fully hand over the stevedoring works to the Stevedoring Company owned by PT Pelabuhan Indonesia II (Persero).

\section{B. Discussion}

\section{The Overview of the Law of Covered Agreement Based on the Law No. 5 on 1999 of the Prohibition of Monopolistic Practices and Unfair Competition in Business}

\section{a. The Development of Law of Business Competition in Indonesia}

In the development of Indonesia's economic system, business competition becomes an instrument of the economy since the Reform Era. In reality, Indonesian people, especially business people, yearn for a law that comprehensively regulates fair competition.

The desire is driven by the emergence of unfair trade practice, especially because the authorities often provide protection or give privilege to certain businesses, as part of the practices of collusion, corruption, crony, and nepotism. The juridical restrictions over unhealthy business practices can be found scattered in various positive laws. However, because of its sectorial traits, this legislation is highly ineffective to (conceptually) meet a 
variety of target indicators which are aimed by the laws of healthy competition. $^{5}$

After so long living under the Government of the New Order regime, Indonesian businesses struggling in unhealthy competitions which triggers the aspiration from the people to start a reformation in the field of business competition in Indonesia. The aspiration arises because the conditions of competition are pro large capital businesses. This kind of government policy existed because of the orientation of economic development focused more on growth so that the principles of equity is forgotten.

A new direction in reforming the world of business competition in Indonesia finally began to open as a result of long financial which was resulted in the resignation of President Soeharto in 1998. With the resignation of President Soeharto, there began a period of reform in all areas, including the reformation in the field of law of business competition. Business competition issues in Indonesia is also a serious concern of the International Monetary Fund (IMF) as a world institution that disburse loans to countries hit by the financial crisis so that the drafting of the Constitution of Business Competition is one of the points required by the IMF in the additional memorandum matrix on the Economic Policy and Finance in the Memorandum of Understanding between the IMF and Indonesia. ${ }^{6}$

All of the above was finally brought 34 members of the House of Representatives from 4 fractions by using the right of initiative, to propose and submit a draft of Business Competition Act on September 2, 1998. The initiative of the House of Representatives is very rare so that when the House of Representatives takes the initiative to propose the Draft of Law on Business Competition, it shows how the law is urgently needed. After went through a long and tough debate in the Parliament, finally on March 5, 1999, Law No. 5 on 1999 concerning Prohibition of Monopolistic Practices and Unfair Competition came into force in Indonesia.

Compared to the process of making laws in general, the process of arranging the Law No. 5 on 1999, was unusual. The difference lies on the party who filed the bill this law. Up to now, the draft of the law was prepared and submitted by the government to be discussed together with the members of the House of Representatives. However, this was not the case with Law No. 5 on 1999.

The House of Representatives prepared the draft which then used the right of initiative to propose a draft. The draft was prepared for more than

\footnotetext{
5 Muladi. Menyongsong Keberadaan UU Persaingan Sehat di Indonesia, dalam UU Antimonopoli Seperti Apakah yang Sesungguhnya Kita Butuhkan?, Newsletter Nomor 34 Tahun IX. Jakarta: Yayasan Pusat Pengkajian Hukum, p. 3.

${ }^{6}$ Ginting, Elyta Ras, Hukum Anti Monopoli Indonesia, Bandung: Citra Aditya Bakti, (2001), p. 3.
} 
four months by the Working Group of the House of Representatives' National Legislation Program on Economic and Industrial Development Affairs with the title of the draft was Law on the Prohibition of Monopolistic Practices, without the words "Unfair Competition."

In reality, the government, in this case, the Ministry of Industry and Trade, has prepared a draft of law which regulates the business competition issues with the title the Draft of Law on Business Competition. Later, the Government and the Parliament agreed on the Draft of Law prepared by the House of Representatives. ${ }^{7}$

In addition to the national demands, the Fair Competition Law is also a demand or need for juridical guidelines in business between nations. Regarding nationality, it is clear that the cultural basis (principle of the familial) and constitutional (economic democracy) we refuse monopolistic practices which would harm the economic life of the people.

In terms of relationship between nations, especially with the emerge of the economic globalization which implies the increasing of interdependence among nations in various fields of life (economy), requires that all nations comply with the standard guidelines (regulations) in business between nations, as a consequence of the WTO, APEC, AFTA, NAFTA, $\mathrm{EC}$, and others. ${ }^{8}$

Many experts said that the existence of the state of competition in the domestic market is very important as part of public policy, in particular for measuring the nation's ability to compete in international markets, as well as to reassure investors and foreign exporters to compete in the domestic market.

Thus the goal of national competition policy is to create competition and ensure that the concept can be executed within the framework of a pluralistic economy. The concept of competitive basis is also essentially containing elements of human rights because it is related to the promotion of condition of rivalry and the freedom of choice to reduce and prohibit the centralization of economic forces. ${ }^{9}$

The doctrine which is applied in the past, which in absolute term stated that the law of economics is value loaded, which is close to the nation's socio-cultural conditions, could not fully be accounted in relation with the process of globalization. The concept of harmonization of the laws and the internationalization of markets phenomenon grow increasingly intensive attention to what is called the international dimension of antitrust and the fit between competition policy and the world trading system. Within

7 Hikmahanto Juwana, Merger, Konsilidasi, dan Akuisisi dalam Perspektif Hukum Persaingan dan UU No. 5/1999, Jakarta: Yayasan Pusat Pengkajian Hukum, (1999), p. 4.

${ }^{8}$ Muladi, Op.Cit., p. 36.

${ }^{9}$ Ibid., p. 36. 
this framework, appear antitrust family (international) links ages of market economies. ${ }^{10}$

Currently, the regulation of business competition in Indonesia comes from Law No. 5 in 1999 on the Prohibition of Monopolistic Practices and Unfair Business Competition, which effectively valid from $5^{\text {th }}$ March 2000. Indeed, the desire to regulate the prohibition of monopolistic practices and unfair business competition can be found in some other laws. The unfair trading practices can be criminally charged under Article 382 of the Code of Criminal Law.

The birth of Law No. 5 in 1999 is also an improvement to the poor economic development, which was proven could not resist the crisis in 1997. The crisis shows us that the economic foundation of Indonesia was weak. Moreover, many opinions say that the Indonesian economy was built deviated from the values contained in Pancasila and the Constitution of 1945.

\section{Closed Agreements in Business Competition Law in Indonesia}

Under the Code Article 1313 of the Civil Code which states that the agreement is an act by which one or more persons bind themselves to one or more persons. This formulation is about to show that the agreements are ${ }^{11}$ :

a. An act;

The acts as mentioned in the initial formulation explain that the agreement is only possible if there is a real action, either in the form of speech, or physical actions and not only in the form of pure thought.

b. Between at least two people (so it can be more than two people);

The agreement which states that there should be at least two people shows that an agreement may not be made by oneself. Thus any action taken by an individual for his benefit does not include as the category of agreements.

c. The act creates an engagement among the parties that agreed;

The statement in the Article 1313 of the Civil Code makes it clear that the agreement involves at least two parties, namely the debtor as the obliged party; and creditor as the party entitled to the debt payments by the debtor, by what has been agreed by the debtor.

Another opinion states that the definition of agreement based on the Code of Civil is incomplete and too broad. The definition is said incomplete because it only mentions unilateral approval. Moreover, the definition is

\footnotetext{
${ }^{10}$ Ibid., pp. 37-38.

11 Muljadi, Kartini; and Widjaja, Gunawan, Perikatan Yang Lahir Dari Perjanjian. Jakarta: Raja Grafindo Persada, (2004), pp. 7-13.
} 
very broad because it uses the words of the act, in which it also includes representatives of voluntary and act against the law.

Therefore, according to R. Setiawan, it is necessary to improve the definition of the agreement, namely: ${ }^{12}$

a. Adding words "or mutually bound themselves" to Article 1313 Code of Civil Law;

b. The act should be interpreted as a legal act; the act aimed to cause legal consequences.

Thus the right definition of the agreement is a legal act, where one or more people tied to each other to bind himself or herself to one person or more. The definition implies that an agreement gives a legal affiliation amongst the parties involved. Each party is bound to one another and has the rights and the obligations between themselves. The legal affiliation between the parties is possible because of the agreement.

According to Kartini Muljadi and Gunawan Widjaja, another consequence arises in making an agreement is that the parties voluntarily bind themselves to give something, to do something or not to do something for the benefit and advantage of other parties who had agreed or committed themselves with assurance in the form of possessions that is owned and will be owned by the party that made the agreement. ${ }^{13}$ Meanwhile, according to Subekti, there should be norms concerning the statements which is considered as the intention of the involved parties to the guidelines before the agreement can be assigned. ${ }^{14}$

It is certain that in various business activities there is competition among businesses. Businessmen will seek to create, pack, and market their products either goods/services as good as possible to attract the consumer Competition in business could have positive implication; on the contrary, it can be negative if it is executed with negative behavior and lead to uncompetitive economic activity. ${ }^{15}$ Some of the advantages of business competition areas-follows:

a. An effective way to achieve optimal utilization of resources.

b. Rivalry tends to suppress costs of production and will result in lower prices lower and higher quality of the products.

c. Competition can be a fundamental foundation for above-average performance for the long-term or sustainable competitive advantage (sustainable competitive advantage) which can be obtained through three generic strategies, the cost advantage, differentiation, and focus on costs.

\footnotetext{
${ }^{12}$ R Setiawan, Pokok-Pokok Hukum Perikatan, Bandung: Binacipta, (2000), p. 49.

${ }^{13}$ Muljadi, Kartini; and Widjaja, Gunawan. Op.Cit., p. 2.

${ }^{14}$ Subekti. Op. Cit., p. 27.

${ }_{15}$ Mustafa Kemal Rokan, Hukum Persaingan Usaha (Teori dan Praktiknya di Indonesia). Jakarta: Raja Grafindo Persada, (2010), p. 1.
} 
In order to prevent businessmen from monopolistic practices and unfair business competition, the Law Number 5 the Year 1999 prohibits businesses to perform certain actions, which can be grouped into a) Prohibited agreements (Article 4 to premises Article 16); b) Prohibited activities (Article 17 through Article 24); c) Dominant Position (Article 25 through Article 29).

Certain actions can be classified into two categories, namely: first, the action taken to "cooperate" with other businessmen; and secondly, actions or legal actions undertaken by businesses and groups of businesses without involving other businesses or groups of businesses.

Various agreements which were prohibited from conducting by businessmen are as follows:

a. Oligopoly agreement;

b. Pricing agreement

c. Price discrimination agreement;

d. Pricing below market prices agreement;

e. Resale with the lowest price agreement;

f. Sharing market area agreement;

g. Boycott agreement;

h. Cartel agreement;

i. Trust agreement;

j. Oligopsony agreement;

k. Vertical integration agreements;

1. Covered agreement;

m. Agreements with foreign parties.

A covered agreement is prohibited by Article 15 of Law No. 5 on 1999. A businessman is free to choose the seller or the buyer or the supplier of a product on the market by the market laws. Therefore, any agreement which contradicts these freedoms and can lead to unhealthy competition is prohibited. An agreement that limits businessmen in choosing buyer, seller, or supplier, is referred to "covered agreement." A covered agreement essentially is the agreement between businesses that includes the following requirements:

a. The party receiving the goods and services will only supply or not supply the goods and services in a particular place (exclusive distribution agreement) Article 15 paragraph (1);

b. The party receiving the goods or services must be willing to buy goods and services from businesses suppliers (tying agreement) Article 15 paragraph (2); and

c. Businessmen who receive the goods and/or services from businesses suppliers (agreement on discount) of Article 15 paragraph (3): 1) must be willing to buy the goods and/or services from businesses suppliers; or 2) 
not going to buy goods and/or services that are identical or similar from other businesses that became a competitor of the supplier.

There are some permitted cases in monopolistic practices and unfair business competition in covered agreements and agreements with outside parties. The legislators give limit or exclusion in Article 50 of Law Number 5 of 1999 , to: ${ }^{16}$

a. Actions and agreement which aims to implement the laws in force;

b. Agreements related to intellectual property rights such as patents, trademarks, copyrights, industrial designs, integrated circuit layout, trade secrets, and plant varieties. Although not explicitly described, this exception applies only to a limited extent and as long as it does not impede business competition and violate the law;

c. Agreements related to the franchise. Although not explicitly described, this exception applies only to a limited extent and as long as it does not impede business competition and violate the law;

d. The agreement related to technical standard-setting products and services that do not restrain and hinder business competition;

e. Agreements with an agency that does not contain provisions for the supply of goods and services at a lower price than the previously agreed price;

f. The agreement related to research to improve the living standards of the community at large;

g. An international agreement that has been ratified by the government of the Republic of Indonesia;

h. Actions and agreement that aims to export that does not interfere with the needs and supply of the domestic market;

i. The business activities of cooperatives that specifically aim to service members;

j. The agreement related to small businesses. Although not explicitly described, this exception is limited because even small businesses cannot violate rules ban monopoly and unfair competition.

These exceptions are the basis of justification on a monopolistic practice and unfair business competition conducted in the form of covered agreements with outside parties. The legislators are also aware that privileged businesses should still be protected.

Not only monopoly and business competition bind the domestic economic system but also the social order of the world economy. These exceptions might become excuses in monopolistic practices and business competition in covered agreements and agreements with outside parties. Business owners can take advantage of this exclusion gap to provide the

\footnotetext{
${ }^{16}$ Mustafa Kemal Rokan. Op.Cit., pp. 230-231.
} 
maximum possible benefit for their business which can injure the principle of balance which is the basic principle of achieving public welfare.

\section{a. Exclusive Distribution Agreement ${ }^{17}$}

Exclusive distribution refers to an agreement between business owners in which includes the requirement that the party receiving the product will only supply or will not supply the products to a particular party, or at a particular place, or in other words, the distributor is forced to supply the products to a particular party and a particular place by businesses owner.

Less or even loss of competition at the level of the distributor affects the price of the products which are more expensive, so consumers have to pay more than usual to get a product that is distributed by the distributor.

Limited distribution may also result in the distributor abusing its exclusive position to charge a high price for a product that is distributed to the consumer in certain areas.

Therefore, Article 15 paragraph (1) of Law Number 5 the Year 1999 prohibits businesses to make exclusive distribution agreement with other businesses. Article 15 paragraph (1) of Law Number 5 Year 1999 formulated per se, so that when businesses make agreements with other businesses which includes the requirement that the party receiving the goods and/or services will only supply or will not supply the goods and/or services to a particular party and/or at a particular place, without having to wait for the result of such actions, businesses that make such agreements can be directly subjected to this article.

\section{b. Tying Agreement ${ }^{18}$}

Law No. 5 the on 1999 is quite hard on the practice of tying agreement, it can be seen from the formulation of the articles about the tying agreement which is formulated per se, which means the business owners who practice the tying agreements with other business owners without having seen the effects of these practices, this article can perfectly be imposed on businesses that violate it.

Article 15 paragraph (2) of Law Number 5 Year 1999 states that; "Business owners are prohibited from making agreements with other parties which requires that the parties receiving the goods and services are willing to buy the goods and services other from the chosen supplier." Article 15 paragraph (2) of Law No. 5 on 1999 also includes the definition of tying agreement which is the agreement made between business owners which

${ }^{17}$ Susanti Adi Nugroho, Hukum Persingan Usaha di Indonesia Dalam Teori dan Praktik Serta Penerapan Hukumnya. Jakarta: Kencana Prenada Media Group, (2012), p. 214.

${ }^{18}$ Ibid., pp. 215-216. 
requires that the party receiving the goods or services must be willing to buy goods or services from business suppliers.

Tying agreements is a type of prohibited agreement by Law No. 5 on 1999 since the practice of tying agreement enables entrepreneurs to expand the power of the monopoly on the tying product (good or service that was first sold) to tie product (goods or services that are forced to be purchased by consumers).

The practice of tying agreements can also cause difficulty to a consumer in determining the actual price of a product, where the consumer only wanted to buy a product, but because it was forced to buy another product that makes consumers confused in determining the price of each product.

Therefore, it can be concluded that there are two reasons that led to the prohibition of the practice of tying agreement, namely; 1) entrepreneur who practices tying agreement does not want other businesses to have an equal opportunity to compete fairly in the tied product; and 2) entrepreneur who practices tying agreement also eliminates the right of consumers to choose the products they want to buy independently. So, it is correct that the Law Number 5 the Year 1999 categorizes tying agreement as one of the prohibited agreements in businesses.

\section{c. Vertical Agreement on Discount ${ }^{19}$}

Article 15 paragraph (3) of Law No. 5 on 1999 states that: "Business owners are prohibited from making an agreement on certain price or discount for the goods and services which includes the requirement that businesses that receive goods and services from a certain supplier:

1) Must be willing to purchase goods and services from certain suppliers; or

2) Will not buy the goods and services that are identical or similar from competitors.

In other words, if business owners get discounted prices for certain products purchased from other businesses, the business owners must be willing to buy other products or agree not to buy the same or similar products from other business competitors.

The consequences which may arise from the agreement above, particularly the obligation for businesses that receive the products at a discounted price, which is required to purchase other products from the supplier, this is actually the same as the consequences caused by tying agreement, which eliminates the right of businesses to choose the products they want to buy freely, and force business owners to purchase products that are not needed.

${ }^{19}$ Ibid., pp. 217-219. 
The obligation for business owners who receive products at discounted prices which is not going to buy the same or similar product from other business competitors can lead to businesses competitors will experience difficulty in selling similar products to the business owners that had previously made a vertical agreement on a discount in the market.

Article 15 paragraph (3) of Law No. 5 on 1999 formulated per se, so that when business owners make agreements as described in Article 15 paragraph (3), without having to wait until the result of the agreement emerges, legal sanctions can be imposed on the agreements that have been made.

A covered agreement is also included in the "vertical" distribution restrictions. Vertical distribution restrictions can be divided into two (2) categories as follows:

1) The establishment of resale prices, such as the maximum or minimum resale prices. In this case, Article 8 of Law No. 5 in 1999 only prohibits minimum price fixing. Meanwhile, the maximum price (for the vertical distribution) is not prohibited;

2) The restrictions on the vertical distribution which is not about the price, for example, the allocation of customers in a particular region or particular customer class to a certain reseller.

As has been explained that the vertical distribution restrictions do not prohibit fixing the maximum price which is regulated by the Law of Business Competition while the one which is prohibited is establishing a minimum price. Although the minimum vertical price fixing is prohibited by Article 8 of Law No. 5 in 1999, it should be carefully applied.

The prohibition of fixing minimum vertical price from the Law of Business Competition should be carefully implemented so that it will not rise to what is called the "free riders." In this case, some parties are unable to take maximum benefit from the toil of its business because others take these benefits.

\section{The Legal Analysis of the Case of Covered Agreement of PT Pelindo II (Persero) In Teluk Bayur, Padang-West Sumatra}

\section{Case Position ${ }^{20}$}

\footnotetext{
${ }^{20}$ Most of the contents of the case closed position of the covenant of PT Pelindo II in this writing quoted by Tempo magazine november edition 2013 with slight changes in by the writer to adjust with this inscription, or may be in a look at the http://www.tempo.co/read/news/2013/11/05/063527203/Monopoli-Pelindo-II-Didenda-Rp47-Miliar (accessed on April, 20, 2015 at 1.25 PM).
} 
PT Pelindo II (Persero) as the business entity that manages the port / operate the terminal and port facilities in ten (10) provinces with the total of 12 (twelve) ports where one port is managed Teluk Bayur Port in Padang, West Sumatra. Teluk Bayur Port as an open port to international trade has increased its business activities related to port services including loading and unloading operations.

At first, the condition of the business activities of loading and unloading goods in Teluk Bayur Port is considered conducive but when PT Pelindo II (Persero) as the business entity is also conducting business on the loading and unloading of goods by forming units special division of the loading and unloading of goods, namely PBM (Perusahaan Bongkar Muat/Company Unloading) DUT (Divisi Usaha Terminal/Terminal Business Division). But in its development, unit/special division that PBM unloading (stevedoring company) DUT (Terminal Business Division) PT Pelindo II Bayur Gulf Branch began to cause problems. Beside acted as the manager of the port, PT Pelindo II (Persero) also establishes requirements in leasing agreement in Teluk Bayur Port by requiring tenants to use the services of loading and unloading of stevedoring company owned by PT Pelindo II (Persero).

In the practice of loading and unloading related to the lease agreements in Teluk Bayur Port, PT Pelindo II (Persero) rents the space in Teluk Bayur Port to third parties, which in the Lease Agreement, PT Pelindo II (Persero) establishes specific requirements which in principle obliges the Third Party (the tenants) to use or give up entirely the work of loading and unloading to the stevedoring company owned by PT Pelindo II (Persero).

PT Pelindo II (Persero) states that from 40 Leasing Agreements, there are only eight agreements that set specific requirement which obliges and or give up completely the work to stevedoring companies owned by PT Pelindo II (Persero). Also, there are 20 leasing agreements between PT Pelindo II (Persero) with a third party which contains a clause requiring the third party to give up fully the work of loading and unloading to the stevedoring companies owned by PT Pelindo II (Persero).

PT Pelindo II (Persero) also confirmed the space leasing in Teluk Bayur Port to third parties which in the leasing agreement, PT Pelindo II (Persero) requires the tenant to use or give up entirely the work of loading and unloading to the Company Stevedoring owned by PT Pelindo II (Persero).

PT Wira Inno Mas, PT Argo Muko, and PT PTPN VI as the partners of PT Pelindo II (Persero) confirmed that the lease agreement with PT Pelindo II (Persero) has a clause which requires to give up fully the loading of palm oil to ship to the stevedoring companies owned by PT Pelindo II 
(Persero) by paying the cost of handling of the loading/unloading to PT Pelindo II (Persero) in accordance with the applicable regulations.

In addition, there is also leasing agreement with PT Karbindo Abesyapradhi that states that PT Karbindi obliged to appoint PT Pelindo II (Persero) as the Stevedoring Company in the loading/unloading of coal from PT Karbindo and PT Karbindo pay the handling of loading/unloading which is carried out by PT Pelindo II (Persero) in accordance with the applicable tariff.

Such actions have the potential impact of unhealthy business competition in the market for stevedoring services at the Teluk Bayur PortSumatera Barat. Meanwhile, as the evidence, there is a lease agreement owned by PT Pelindo II (Persero) also contained clause liabilities for the tenants which must meet the minimum number of annual throughput. If does not meet, then the tenants will be penalized as calculated per/ton of the remaining amount of the minimum throughput that is not fulfilled. Therefore, based on the evidence there is also leasing agreement regulate the prohibition to handle the loading and unloading of a third party if it is done it must obtain permission from PT Pelindo II (Persero) and must pay a supervision fee to PT Pelindo II (Persero).

PT Pelindo II (Persero) rejected the description of the alleged violation of Law No. 5 on 1999 Related Stevedoring Services in Teluk Bayur Port. One of the arguments from PT Pelindo II (Persero) in conducting port service is that the stevedoring services is one of the port's services and has been regulated in:

a. Government Regulation No. 57 on 1991 on the Transformation of Public Corporation (Perum) of Port II to a Limited Liability Company (Persero), namely Article 2 letter c, which reads: "The purpose of Company Limited (Persero) as referred in Article 1 is to conduct business as follows: c. Dock to tie up, loading and unloading, goods and animals, as well as the facilities for the passengers;

b. The Certificate of Establishment of PT Pelindo II (Persero) Number 3, December $1^{\text {st }}, 1992$, namely Article 3 (2) c, which reads: "To achieve the above objective The Company has ongoing work in the field: c. Piers and other facilities for tethered, loading and unloading of goods, including animals, and facilities for passengers;

c. Law No. 17 on 2008 of Sailing, namely Article 344 paragraph (3), which reads: "The activities of the port that have been organized by the State Owned Enterprises still held by the State-Owned Enterprises." Based on the explanation of Article 344 paragraph (3), what is meant by "still held by the State-Owned Enterprises" is a State Owned Enterprise which was established under the Government Regulation No. 56 on 1991, Government Regulation Number 57 Year 1991, Government Regulation 
Number 58 Year 1991, and Government Regulation No. 59 on 1991, still conducting business activities in the ports that include a. the activities set out in Article 90 paragraph (1), paragraph (2), (3) and (4) of this Act, which among other activities are "provision and/or services of ships, passengers and goods as referred in paragraph (2) shall consist of: provision and/or stevedoring services "as regulated in Article 90 paragraph (3) g;

d. PT Pelindo II (Persero) is a Port Business Entity as referred to in Article 1 point 28 jo. Article 92 of Law No. 17 on 2008 on the voyage;

e. Based on the Decree of the Minister of Communication Number: KP 98 Year 2011, PT Pelindo II (Persero), licensed as Port Business Entity (BUP) with line of business in terminals and other facilities management, among others are conducting concession for the provision of port services and/or services of loading and unloading of goods. Therefore, under the terms of a quo, the establishment of Port Enterprises, in this case, PT Pelindo II (Persero) is a command and based on the Law of Voyage;

f. PT Pelindo II (Persero) as a Business Entity Ports under Article 92 jo. Article 93 of the Shipping Law, acts as the operator which operates the terminals and other port facilities may perform the provision and / or service port that is implemented by Enterprise Port as referred to in Article 91 paragraph (1) which states that the activity of providing and/or services as referred to in Article 90 paragraph (1) at the port of cultivated commercially implemented by the Port Enterprises according to the type of its business license.

Thus PT Pelindo II (Persero) as a Business Entity Ports conducting commercial exploitation of port services including stevedoring services activities is acting under the Law.

In this issue, PT Pelindo II (Persero) as Enterprises Port also considers not to justify the conducting business activities of loading and unloading of goods with forming units/special division of the loading and unloading of goods, namely PBM Company (stevedoring) which has a potential monopoly in a systematic, structured and planned to reduce and/or obstructing the company's role in running the business of loading and unloading in the port of loading and unloading, for the following reasons:

a. The implementation of the activities of loading and unloading services activities by PT Pelindo II (Persero) has been implemented since PT Pelindo II (Persero) was established to conduct port services, not made lately;

b. The Constitutional Court on December 5, 2011, ruled that the core ever decision rejecting petition is declared Article 90 paragraph (3) letter $\mathrm{g}$ contrary to the Constitution. 
Thus, the activities service the unloading goods by PT Pelindo II (Persero) the Branch of Teluk Bayur through division business terminal has the potential to cause the impact of business competition unhealthy in the market services unloading goods in Teluk Bayur Port, West Sumatra province is not true.

While alleged after, PT. Pelindo II (Persero) formed a unit/a specialized division of related business activities services unloading goods in Teluk Bayur Port have resulted in the condition unloading goods in Teluk Bayur Port to not conducive and gives rise to alleged problems also not justified, by reason as follows:

a. The implementation of the activities of these services unloading by PT Pelindo II (Persero) has been implemented since PT Pelindo II (Persero) established to perform activities in the port services, not formed recently;

b. The allegation contrary to the flow of goods in Teluk Bayur Port from the year 2006, 2007 until 2011, where the flow of goods from the year 2006, 2007 until 2011 continue to rise constantly;

Similarly, activity loading and unloading are done by 25 PBM (a company loading and unloading) also increase almost all service companies loading and unloading that are by their portion, even PT. Stevedoring Putra Mandiri with the total number of loading and in 2010 only 243.531, in 2011 is a sharp increase jumped to 1.273.533; the data prove the allegation that the condition being not conducive due to PT. Pelindo II (Persero) do activities services unloading goods is not true.

While mastery market services are loading and unloading according to PT. Pelindo II (Persero) in Teluk Bayur Port of between $33 \%$ to $47 \%$ is not held by means of violating Article 25 verse 1 Law No. 5 on 1999, the use of a position dominant either directly or indirectly through the determination of requirements special in agreement land lease with the provisions of obliging uses and/or fully devolved work loading and fit on PBM (a company loading and unloading) DUT (division business terminal) PT Pelindo II (Persero) the Branch of the Teluk Bayur. It is based because in Teluk Bayur Port there was no requirement for those users port, for hire land, warehousing and places the accumulation at in the area of the port, so consumers are free to choose services which are most favorable according to the consumers.

In addition, according to PT Pelindo II (Persero), it also never hinder, limit, set consumers to use the terminal and port managed by PT Pelindo II (Persero) and even PT Pelindo II (Persero) once seek to advance another PBM by way of inventory with recording repeated performance against PBM that is in Teluk Bayur Port but rejected. And mean data collection for mapping performance, to be done synergies better, because PT Pelindo II (Persero) as PBM as stipulated in Article 94 letter a the Law of Shipping. 
The fact in the field according to PT Pelindo II (Persero) that many companies loading and unloading in Teluk Bayur Port who do not have the quality of services to support the performance Teluk Bayur Port as determined by the government and the responsibility for the performance is in PT Pelindo II (Persero) as the business entity port. Hence with the quality of bad services will impact the activities to smooth the flow of goods go in and out of port and causing the logistics high costs, and finally can result in a high economic cost.

Also, according to PT Pelindo II (Persero), there has been no standardization performance PBM that is in Teluk Bayur Port to ensure customer satisfaction, and the target of performance reached. Thus, it can then be considered not against the law if PT Pelindo II (Persero) set standards performance based on the reached standards performance of PT Pelindo II (Persero) Law Number 17 the Year 2008 paragraph 3 the Port, mentioned in Article 81, Article 82, and Article 91.

While the requirements of the use of PBM according to PT Pelindo II (Persero) for no tenants have been final but rather an alternative because it can use another PBM but in supervision PT Pelindo II (Persero), this requirement should be put because there was no standardization PBM in Teluk Bayur Port, not all PBM that has the tools and performance the speed equal to PBM PT Pelindo II (Persero), and performance evaluation of a seaport was determined by the services loading, so supervision was the embodiment of the responsibilities given by statute to ensure the smooth traffic flow goods in port, because the more rapid and efficient traffic flow goods in port the adds to the value of positive for economic growth supported by the port in this matter is West Sumatra Province.

Conditional agreement about the rent of land addressed to anyone interested in higher land in the area port, has no limitation on certain groups because the party of a tenant could be anybody, the restrictions at least result, is meant to make a tenant reckon carefully achieve the target, because by doing calculation at least result to be achieved then PT Pelindo II (Persero) is running law, because if the land hired by a tenant which did not reach the result, it would mean "defendant" did not practice the message of law use port facilities not advantageous commercial, because the area of land port which house limited is a tenant that has a high and benefit commercial height to which it will be approved and be bound in the agreement.

PT Pelindo II (Persero) also denied making a pact per se illegal violated Article 15 paragraph (2) Law No. 5 on 1999. An assessment of rent is breaking law or not to be assessed first, whether the agreements of PT Pelindo II (Persero) run on law and or based on law or not. But it can be seen from the above that it can be concluded the act of PT Pelindo II (Persero) of the act of exceptions as referred to in Article 50 letters a. Violation Article 
19 letter $\mathrm{a}$ and $\mathrm{b}$ did not happen because that is no decree for those to do rental land, accumulation of goods out of the areas of business entity to the port, tariff transport service goods determined by association PBM, PT Pelindo II (Persero) never hinder, limit flow of goods and set consumers should use services PT Pelindo II (Persero) if hire land, accumulation of outside of harbors.

\section{Opinion and Legal Analysis}

Basically who are the objects of this thing covenants land lease between PT Pelindo II (Persero) with a third party in Teluk Bayur Port containing the regulation that PT Pelindo II (Persero) obligates third party fully devolved work unloading goods belonging to the third party to a company loading and unloading owned by PT Pelindo II (Persero). Meanwhile, the capacity of PT Pelindo II (Persero) as company loading and unloading especially in Teluk Bayur Port should be line with the company loading and unload in performs activities services loading and unload in port.

In this case, there is some fact law as follows:

a. There are 40 (forty) covenant rental lands indicating there are closed agreement with imposing special requirements regarding in agreement land lease with the provisions of obliging and or fully devolved work on company loading and unloading owned by PT Pelindo II (Persero);

b. In addition, in this case also obtained the fact that there were 20 (twenty) covenant land rental between PT Pelindo II (Persero) with a third party containing clause obliging the third party fully devolved work loading and unloading to a company loading and unloading owned by PT Pelindo II (Persero), as in PT Wira Inno Mas, PT Argo Muko, and PT Perkebunan Nusantara VI as one of partners PT Pelindo II (Persero) which is fully devolved the implementation of the load oil palm to the ship to a company loading and unloading owned by PT Pelindo II (Persero) with pay a fee handling loading and/load to PT Pelindo II (Persero) based on the regulation;

c. PT Pelindo II (Persero) also confirmed the land rental in Teluk Bayur Port to a third party wherein agreement with the land PT Pelindo II (Persero) with the terms to the a tenant land to design using and or fully devolved work loading and unloading to companies loading and unloading owned by PT Pelindo (Persero) when goods belong to a tenant land will be in loading and or loaded from and to the ship, as is the case with PT Karbindo Abesyapradhi.

Therefore, there is a Land Lease Agreement between PT Pelindo II (Persero) and Third Party by issuing clause of delivery of loading and 
unloading activity to Third Party Goods to the loading and unloading company owned by PT Pelindo II (Persero).

Thus, it has land lease agreement between PT Pelindo II (Persero) with a third party by covering the clause of the activities in loading and unloading on goods done by the third party to a company loading and unloading owned by PT Pelindo II (Persero).

The agreements of the use of the land at ports (in this case Teluk Bayur Port) by requiring land users with mandatory use of loading and unloading companies owned by PT Pelindo II (Persero) are not implicitly or explicitly stipulated as mandated by the laws and regulations applicable in particular Law Number 172008 concerning Shipping, so that the business of loading and unloading services owned by PT Pelindo II (Persero) is not an exemption and/or an exceptional agreement as regulated in Article 50 letter an of Law Number 5 the Year 1999 concerning Prohibition of Monopolistic Practices and Unfair Business Competition. Agreements made by PT Pelindo II (Persero) with Third Parties should comply with the limits in the principle of freedom of contract namely the provisions of the law (in this case Law No. 5 of 1999 on Prohibition of Monopolistic Practices and Unfair Business Competition), public order, and good morals.

Agreement of land use in port (in this case Teluk Bayur Port) with in conditions users land by are obliged to use company loading and unloading owned by PT Pelindo II (Persero) are not arrange in implicit and explicit firmly according to what is ordered legislation that prevail particularly Law Number 17 Year 2008 on Shipping, so business activities services loading and unloading owned by PT Pelindo II (Persero) not is of the work and/or agreement of being excluded as stipulated in Article 50 letters a the Law Number 5 Years 1999 on Prohibition of Monopoly and Unfair Business Competition. The agreements by PT Pelindo II (Persero) with a third party should obey restrictions in principle freedom contract that is the provisions of a statute (in this case the Law No. 5 on 1999 on Prohibition of Monopoly and Unfair Business Competition), public order, and decency good.

The Land Lease Agreement between PT Pelindo II (Persero) and Third Party is a tying product while the clause of appointment of a loading and unloading company owned by PT Pelindo II (Persero) to the land tenant is a tied product and the agreement is contradictory to the principle of healthy business competition especially Article 15 paragraph 2) of Law Number 5 Year 1999 concerning Prohibition of Monopolistic Practices and Unfair Business Competition, with the fulfillment of the following elements:

Land lease agreement between PT Pelindo II (Persero) with the third is tying product while clause the appointment of company loading and unloading owned by PT Pelindo II (Persero) for the tenant land acquisition is tied product and the agreement contravenes the principle business 
competition healthy in particular the Article 15 paragraph (2) of the Law Number 5 Year 1999 on Prohibition of Monopoly and Unfair Business Competition, with the fulfillment of element as follows:

a. Tying products, by Article 1 point 16 and Guidance Article 15, the Goods are any tangible or intangible good, whether mobile or immovable, which may be traded, used, used or utilized by the consumer or perpetrator business. Correctly, the land rented by PT Pelindo II to other parties, in this case, the owner of the goods is a tangible and immovable object that can be used, used and utilized. Therefore the element of goods is fulfilled;

b. Elements of other goods and or services, under the guidance of Article 15 which states that the services of any services in the form of work or achievements traded in the community for use by consumers or business actors. The correlation in the land lease agreement made by PT Pelindo II (Persero) to the tenant of the land contains a clause which principally states that the party who leases the land is obliged to submit the loading and unloading activities of his/her goods to be carried out by the PT. Sindo Pelindo II (Persero Bongkar Muat) ). Also, the loading and unloading activities carried out by PT Pelindo II (Persero) in Teluk Bayur port area are services that are traded because they have loading and unloading rates and can be utilized by business actors, in this case, the owner of the goods. Thus, other service elements are met.

c. Element goods (the tying product), based on Article 1 number 16 and Guidelines Article 15, goods is any inanimate object good tangible and intangible, either moving and not moving, who can be traded, used, be used, or used by consumers or business operators. Correlation, land leased by PT Pelindo II to other parties in this the owner goods is tangible and or immovable asset that can be used, be used and used. Hence the element goods are fulfilled;

d. Element goods and or services for another, with the guidebook Article 15 said that services any service shaped work or achievement traded in society to use by consumers or business operators. Correlation in agreement land lease done by PT Pelindo II (Persero) to the tenant land load clause that in principle that states that the one who hires land are obliged to submit activities loading and to unload for goods were held by the loading and unloading owned by PT Pelindo II (Persero). Also, activities are loading and unloading held by PT Pelindo II (Persero) in the Teluk Bayur Port; service was whose occupation sold because it has tariff loading and unloading and can be used for business operators, in this case, the owner goods. Thus, element other services fulfilled.

Based on Article 15 paragraph (2) of the Law Number 5 the Year 1999 can also be seen the definition of tying agreement, namely the 
agreements of business doers that contain the requirement that the receiving party is goods or services certain should be willing to purchase goods or services other than business players suppliers. Tying agreement is one of category agreement which has been banned by the Law 5/1999, as by practices tying agreement business players which can have the monopoly power have on the tying product (goods or services are first coming out) to the tied product (goods or services forced have to also bought by consumers). Correlation with having the power monopoly to either product at once (tying product and tied product) for business operators, can create obstacles for the future business players as a competitor to surge in the market, so inevitably business players must do the same, is to do tying practices.

For consumers who did not understand about tying agreement practices might do buying a product and then get additional other products, regarded as a gift. Although exactly the price paid is a price of both products that received. Tying agreement practices can also make consumers difficult in determining the actual price of a product that he buys, where formerly he just wants to buy one product, but because of forced must buy products that other so making consumers become confused how the price of each product.

Tying agreement has also made consumers must buy merchandise that is not needed. While reasons why the tying practices agreement was banned among others: 1) business doers that do tying agreement does not want the other businesses have had the same opportunities to compete in fair with him on tied product; and 2) business doers that do practices tying agreement has also deprived of the right of consumers to vote in free goods that they want to buy. So, its right Law No. 5/1999 categorizes tying agreement to be wrong an agreement which has been banned from doing for business operators. ${ }^{21}$

In addition, the agreement rent land that bind between PT Pelindo II (Persero) and the tenants of land not adheres to the principles of fair competition in or do not heed the principles of fair competition in as stipulated under the Law Number 5/1999 of the Prohibition of the Practice of a Monopoly and Unfair Business Competition. Thus rent land agreement between PT Pelindo II (Persero) with a third party not constituting of the covenant that is excluded by Article 50 the Law Number 5/1999 on Prohibition of the Practice of a Monopoly and Unfair Business Competition.

In the case of increasing market share through land lease agreement, based on the description of the position case in principle, PT Pelindo II (Persero) acknowledges that the policy of Land Lease Agreement which contains the clause of handling of loading and unloading activity to the

${ }^{21}$ Susanti Adi Nugroho, Op.Cit., pp. 216-217. 
loading company owned by PT Pelindo II (Persero) all ports managed by PT Pelindo II (Persero) or can be said policy of Land Lease Agreement to increase market share of PT Pelindo II (Persero) loading and unloading company.

While the ports and all their infrastructure (including lands leased in the port area) are essentially essential facilities so that the increasing market share by PT Pelindo II (Persero) through land clearing agreements is more effective because PT Pelindo II (Persero) owns the essential facility, i.e. land within TelukBayur port. Therefore, regarding product characteristics, the essential facility has no substitution because it is objectively and rationally cannot be duplicated, and the product has a very important role to serve as an instrument for business actors to compete well in the upstream market ) as well as in the downstream market (downstream market).

In terms of an increase in market share by covenant land lease, based on the discussion cases position in principle PT Pelindo II (Persero) in fact admitted that the policies agreement land lease containing clause the activities loading and unloading to a company loading and unloading owned by PT Pelindo II (Persero) valid for all port managed by PT Pelindo II (Persero) or it can be said policy agreement land lease to expand its market company loading and unloading PT Pelindo II (Persero).

While port and all the infrastructure (including land leased in the port) those to whom we have is essential facility, therefore, enhancing the market share done by PT Pelindo II (Persero) by covenant hire land had been more effectively because PT Pelindo II (Persero) mastered essential facility the land in Teluk Bayur Port. Because from the characteristic of their products essential facility not having substitution because objectively and rational cannot duplicate and the products have a very important role to be used as an instrument for business operators to compete well in the upstream market or the downstream market.

The correlation is then for the tenant of the land has no choice but to use the land in Teluk Bayur Port. Also, land lease agreements that require the appointment of loading and unloading company owned by PT Pelindo II (Persero) is an attempt to abuse the dominant position of PT Pelindo II (Persero) to increase its market share.

Therefore, land lease agreement between PT Pelindo II (Persero) and Third Party which includes the clause of delivery of loading and unloading activities to a company owned by PT Pelindo II (Persero) done in order to increase market share cannot ignore or override norms of fair business competition regulated in Law Number 5 Year 1999 concerning Prohibition of Monopolistic Practices and Unfair Business.

Correlation then for the tenant land no choice but to use land in Teluk Bayur Port. Besides the agreement land lease requiring the appointment of 
company loading and unloading owned by PT Pelindo II (Persero) is an effort abuse the position of women dominant PT Pelindo II (Persero) to increase for its market share.

Thus, the land lease agreement between PT Pelindo II (Persero) with third parties include clauses unloading activities deliverables to company PT Pelindo II (Persero) was conducted in order to improve market share cannot ignore or throw over the norms of healthy business competition as set forth in Law Number 5/1999 of the Prohibition of the Practice of a Monopoly and Unfair Business Competition.

The land lease agreements which include clause of handling loading and unloading activities to PT Pelindo II (Persero) loading and unloading companies also reduce and even eliminate opportunities for competitors to operate in the relevant market. The behavior and policies of PT Pelindo II (Persero) have proven that the closure has prevented the access of loading and unloading service market for other loading and unloading companies which become competitors of PT Pelindo II (Persero).

The policy of PT Pelindo II (Persero) is also clearly a market obstacle because with the clause it has closed the opportunity for loading and unloading company (other than PT Pelindo II (Persero)) to provide goods loading and unloading services to the land tenant (tenant) the. While the supervision of fees to land users who do not use the loading and unloading services of PT Pelindo II (Persero) is clearly also a market obstacle because factually it has increased production costs in loading and unloading services by other loading/unloading companies or at least have reduced incentives in using other loading and unloading services other than PT Pelindo II (Persero).

The actions of PT Pelindo II (Persero) which include a clause of handing overloading and unloading activities to a loading and unloading company owned by PT Pelindo II (Persero) is also an action to prevent consumers or competitors' business customers from conducting business relationships with their competitors.

Agreement land lease in clause submit activities loading and unloading to a company loading and unloading owned by PT Pelindo II (Persero) also reduce even miss an opportunity for business operators competitors to operate in the market concerned. Behavior and policies PT Pelindo II (Persero) it has proved the existence of the closure or has prevented market access services loading and unloading for the company loading and unloading other become main competitors PT Pelindo II (Persero).

The policy of PT Pelindo II (Persero) also are obstacles market because with the clause has closed an opportunity for company loading and unloading (other than PT Pelindo II) to provide services unloading goods to 
a company using a tenant land of was. While supervision fee to the owner of the ground land who do not use services loading and unloading PT Pelindo II (Persero) clearly is also a obstacles the market because factually has increased production cost in services loading and unloading who company did loading and unloading another or at least have reduced incentives in use the loading and unloading other than PT Pelindo II (Persero).

The act of PT Pelindo II (Persero) in clause submit activities loading and unloading to a company loading and unloading owned by PT Pelindo II (Persero) is also the act of obstructing consumers or subscriber business players rival not to do business relationship with entrepreneurs rival.

\section{E. Conclusion}

1. In the legal review of the closed treaties referred to in articles 15 and 19 of the Act. 5 of 1999 concerning the Prohibition of Monopolistic Practices and Unfair Business Competition, it can be concluded that closed agreements made in a business relationship tend to be profitable for those parties to the closed treaty and harmful to others who are not within the covenant circle. Also, agreements made may lead to monopolistic practices in business competition. Therefore, it is necessary to take care and supervise both by the government through KPPU and by involving the community to participate in supervision. It is needed to enforce the rule of law in Indonesia can be executed expressly.

2. The case of Land Lease Agreement between PT Pelindo II (Persero) and Third Party is tying product while the clause of appointment of loading and unloading company owned by PT Pelindo II (Persero) for tenant is a tied product and the agreement is contradictory to the principle of healthy business competition especially Article 15 paragraph (2) of Law No. 5 in 1999 of Prohibition of Monopolistic Practices and Unfair Business Competition. Land lease agreements which include clause of handling loading and unloading activities to PT Pelindo II (Persero) loading and unloading companies also reduce and even eliminate opportunities for competitors to operate in the relevant market. The behavior and policies of PT Pelindo II (Persero) have proven that the closure has prevented the access of loading and unloading service market for other loading and unloading companies which become competitors of PT Pelindo II (Persero).

3. Based on law review about closed agreements as mentioned in Article 15 and 19 Law Number 5/1999 on Prohibition of a Monopoly and Unfair Business Competition can be concluded that the closed agreements that done in a relationship business tended to benefit for people who did the closed agreements and the harmful for another party not be in a circle the agreement. Also, agreement done could cause practices monopolistic 
in business competition, hence required attention and supervision good being done by the government through KPPU (Komisi Pengawas Persaingan Usaha) and involved the community in participating in supervision. It needed to make the rule of law enforcement in Indonesia can be undertaken in a firmly.

4. Cases of land lease agreement between PT Pelindo II (Persero) with the third is tying product while clause the appointment of company loading and unloading owned by PT Pelindo II (Persero) for the tenant land acquisition is tied product and the agreement contravenes the principle business competition healthy in particular the Article 15 paragraph (2) of the Law Number 5/1999 on Prohibition of Monopoly and Unfair Business Competition. Agreement land lease in clause submit activities loading and unloading to a company loading and unloading owned by PT Pelindo II (Persero) also reduce even miss an opportunity for business operators competitors to operate in the market concerned. Behavior and policies PT Pelindo II (Persero) it has proven the existence of the closure or has prevented market access services loading and unloading for the company loading and unloading other become main competitors PT Pelindo II (Persero).

\section{A. Book}

\section{Bibliography}

Nugroho, Adi; and Susanti. (2012). Hukum Persingan Usaha di Indonesia Dalam Teori dan Praktik Serta Penerapan Hukumnya. Jakarta: Kencana Prenada Media Group.

Hartono, Sri Redjeki. (2007). Hukum Ekonomi Indonesia. Malang: Bayumedia.

Juwana, Hikmahanto. (1999). Merger, Konsilidasi, dan Akuisisi dalam Perspektif Hukum Persaingan dan UU No. 5/1999. Jakarta: Yayasan Pusat Pengkajian Hukum.

Muljadi, Kartini. and Widjaja, Gunawan. (2004). Perikatan Yang Lahir Dari Perjanjian, Jakarta: RajaGrafindo Persada.

Muhammad, Abdulkadir. (1986). Hukum Perjanjian, Jakarta: Citra Adtya.

Muladi, Menyongsong Keberadaan UU Persaingan Sehat di Indonesia, dalam UU Antimonopoli Seperti Apakah yang Sesungguhnya Kita Butuhkan?, Newsletter Number 34 IX, Jakarta: Yayasan Pusat Pengkajian Hukum.

Rokan, Mustafa Kemal. (2010). Hukum Persaingan Usaha (Teori dan Praktiknya di Indonesia). Jakarta: Raja Grafindo Persada.

Ginting, Elyta Ras. (2001). Hukum Anti Monopoli Indonesia, cet. 1. Bandung: Citra Aditya Bakti. 
Setiawan, R. (2000). Pokok-Pokok Hukum Perikatan. Bandung: Binacipta. Subekti. (1996). Hukum Perjanjian, Jakarta: Intermasa.

Widjaja, Gunawan. (2007). Memahami Prinsip Keterbukaan (Aanvullend Recht) Dalam Hukum Perdata, Jakarta: Grafindo Persada.

Yani, Ahmad and Widjaja, Gunawan. (1999). Seri Hukum Bisnis Anti Monopoli. Jakarta: Rajawali Pers.

B. Article/World Wide Web

Tempo Magazine November Edition 2013 or maybe in a look at http://www.tempo.co/read/news/2013/11/05/063527203/MonopoliPelindo-II-Didenda-Rp-47-Miliar 